\title{
A Proposed Model of Metamaterial Complementary Split- Ring Resonator to Reduce Microstrip Array Antenna Dimension
}

\section{Efri Sandi, Rizqiana Putri, and Aodah Diamah}

Electronic Engineering Education Studies Program, Engineering Faculty, Universitas Negeri Jakarta, Jalan Rawamangun Muka Jakarta Timur, Indonesia 13220.

\section{Abstract}

This study aims to develop a model of complementary split-ring resonator (CSRR) metamaterial structure to reduce microstrip array antenna dimensions. The smaller antenna dimensions are needed in communication system applications such as cellular devices and loT sensors. It is necessary to miniaturize the antenna size to provide compatible antenna size with the development of wireless communication systems. This study was developed by designing the CSRR model on the microstrip array antenna at $2300 \mathrm{MHz}$ LTE frequency band and using FR-4 Epoxy substrate material.

Corresponding Author: Efri Sandi

efri.sandi@unj.ac.id

Received: 11 January 2019 Accepted: 14 February 2019 Published: 25 March 2019

Publishing services provided by Knowledge E

(c) Efri Sandi et al. This article is distributed under the terms of the Creative Commons

Attribution License, which permits unrestricted use and redistribution provided that the original author and source are credited.

Selection and Peer-review under the responsibility of the 3rd ICTVET 2018 Conference Committee.

\section{G OPEN ACCESS} The simulation and measurement results show the microstrip array antenna with the addition of CSRR structure that has 31\% smaller dimension compared to without using CSRR structure. The radiation performances with the addition of CSRR structure also shows a significant improvement of bandwidth and return loss with a slight decrease in gain. This study proves that the addition of CSRR structure is one of the solution to miniaturization of microstrip antenna.

Keywords: CSRR metamaterial, antenna dimension, radiation performances

\section{Introduction}

The rapid development of wireless communication systems such as cellular communication systems, wireless sensor networks and loT devices, requires a smaller size of device. Likewise, the required antenna on the communication system device becomes smaller [1]. It is necessary to miniaturize the antenna size to provide compatible antenna size with the development of wireless communication systems.

Microstrip antennas is one type of antenna that is widely engineered to produce smaller sizes and compatible with wireless communication system devices. Microstrip antennas have been the subject to study in many years because physical size, low profile and easy to fabricate, even though it has disadvantages such as narrow bandwidth and relatively smaller gain [2]. 
One solution to reduce the size of microstrip antennas is by using split-ring resonator (SSR) and complementary split-ring resonator (CSRR) metamaterial structures $[3,4]$. CSRR is a structure that can be printed on the ground or patch antenna. The CSRR material composition is the opposite of SRR which consists of two slot rings (circle or rectangular) where the inner and outer slots are separated by a metal/copper strip $[4,5]$.

The equivalent circuit of CSRR is quite simple with an inductance and a parallel installed capacitance (parallel LC). Inductance and capacitance values are determined by the width of the CSRR ring and slot $[5,6]$. By using this concept, the addition of the CSRR structure to a microstrip antenna can reduce the antenna size of the ultrawideband (UWB) antenna size significantly [7]. The additional of the CSRR structure design is also reducing the size of the MIMO antenna and the multiband antenna $[8,9]$.

In this paper, design and modified metamaterial CSRR structure to reduce antenna size is proposed. The design will develop by using microstrip array antenna at 2300 $\mathrm{MHz}$ LTE frequency band. This design was developed to reduce antenna size significantly with control antenna performances degradation.

\section{Design of Antenna and CSRR Structure}

\subsection{Antenna design}

The proposed microstrip antenna is designed numerically by using CST microwave studio software to operate at $2300 \mathrm{MHz}$ LTE band frequency. Design of microstrip antennas using FR4-Epoxy substrate with a thickness of $1.6 \mathrm{~mm}$. The Overall microstrip antenna dimensions resulting from design optimization are $44.1 \mathrm{~mm} \times 40.1 \mathrm{~mm}$ for substrate material and $35.25 \mathrm{~mm} \times 29.4 \mathrm{~mm}$ for patch antennas as shown in Figure 1.

In this study to observe the effect of CSRR structure, the sample array antenna was designed with 2 elements as shown in Figure 2. Microstrip array antennas are designed using feeding system for two elements with $\lambda / 2$ spacing between patch elements.

\subsection{CSRR structure design}

The addition of the CSRR structure begins with calculating the geometry of one cell, than will continue to adding the number of orientation cells $4 \times 4$. The initial stage of designing a CSRR cell to find the $\lambda / 2$ lengths for the outer ring resonator, and $\lambda / 4$ for 


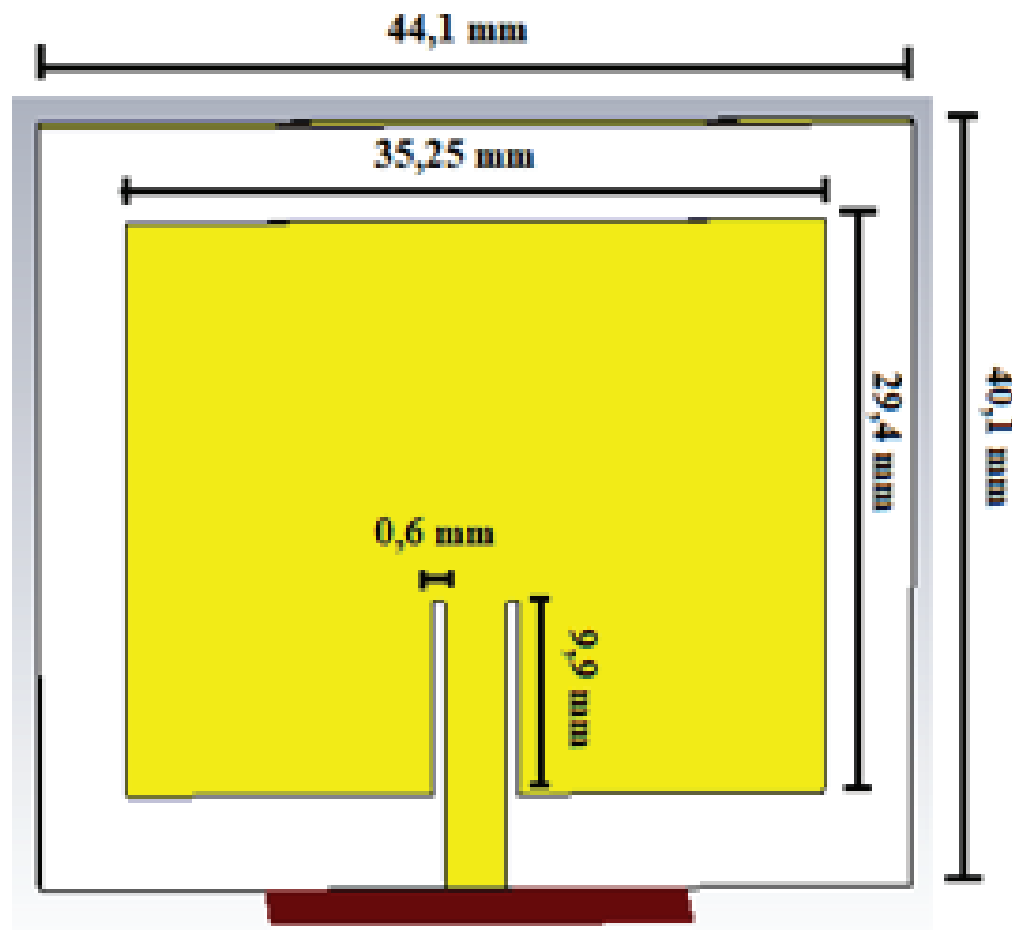

Figure 1: Single Element Design Microstrip Antenna.

$112,66 \mathrm{~mm}$

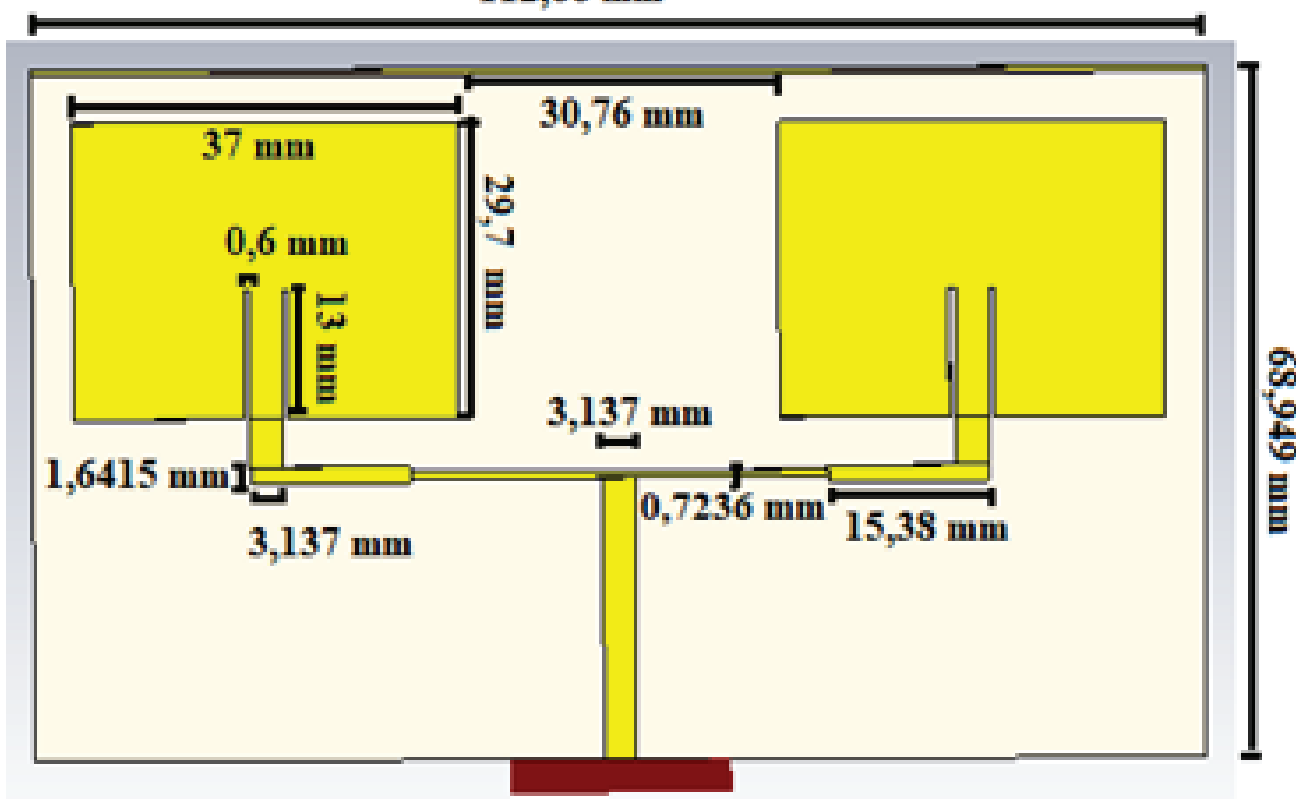

Figure 2: Design of 2 Elements Array Antenna.

the inner ring resonator. The next step to determine the design of the outer and inner ring through approximation as shown in Figure 3.

The proposed outer ring approach for CSRR design, $A=B=C ; D=E$; and put approximation for $F=0,5 \mathrm{~mm}$. Using the same approach to inner ring, $I=J=K$; $M=L$; and put approximation for $N=0,5 \mathrm{~mm}$. For the distance between rings $(d)$ and 
the width of the ring $(t)$ is equal, so that the values of $\mathrm{H}$ and $\mathrm{L}$ can be calculated by $B-J$. In this design, we proposed $d=t$ and $G=H$. All calculations for the dimensions of the CSRR structure are proposed as shown in table 1.

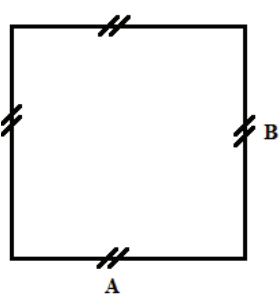

(a)
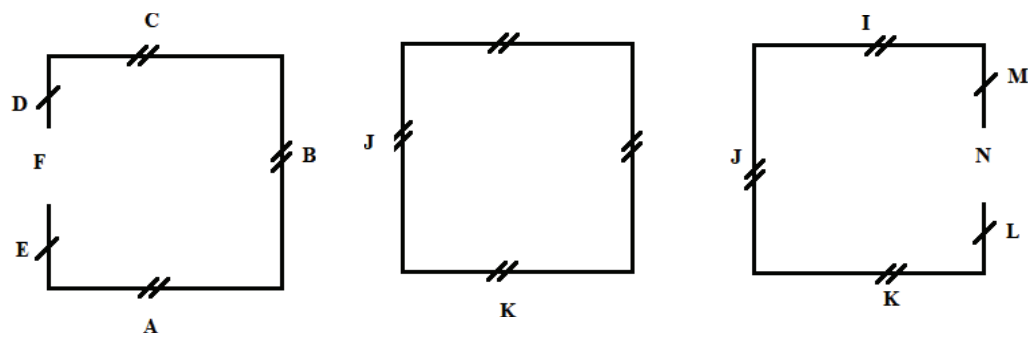

(b)

Figure 3: Design CSRR Structures, outer ring (a) and inner ring (b).

TABLE 1: Dimension of single cell CSRR structure.

\begin{tabular}{|c|c|}
\hline \multicolumn{2}{|c|}{ Outer Geometry Elements of CSRR } \\
\hline Side & Length (mm) \\
\hline A & 7.7 \\
\hline$B$ & 5.8 \\
\hline C & 7.7 \\
\hline D & 5.8 \\
\hline$E$ & 3.6 \\
\hline $\mathrm{F}$ & 0.5 \\
\hline \multicolumn{2}{|c|}{ Inner Geometry Elements of CSRR } \\
\hline Side & Length (mm) \\
\hline 1 & 3.9 \\
\hline O & 2.0 \\
\hline J & 3.9 \\
\hline M & 2.0 \\
\hline$P$ & 1.7 \\
\hline $\mathrm{N}$ & 0.5 \\
\hline
\end{tabular}

The proposed CSRR structure design as shown in Figure 4.

The next step is the iteration step to create a $4 \times 4$ cell orientation, where the size of one cell is reduced because will be impact to the matching level, especially for gain will be negative value. The reduction of CSRR dimensions and $4 \times 4$ orientation design in patch array antenna as shown in Figure 5. 


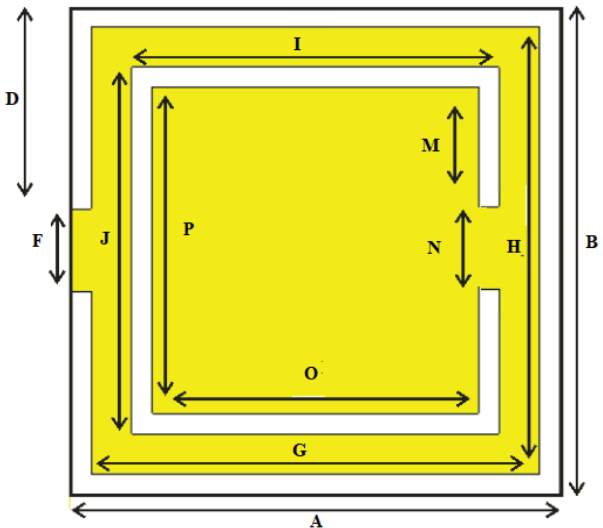

(a)

Figure 4: Proposed CSRR Design, outer and inner ring dimension (a), ring distance, and width (b).

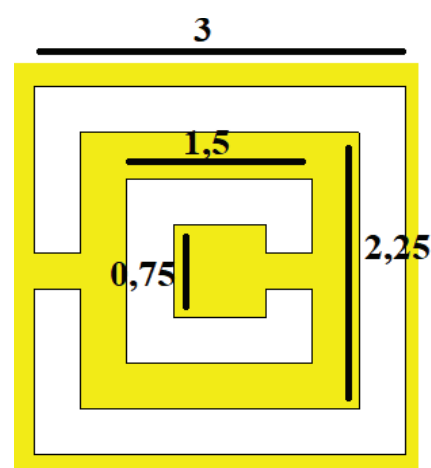

Figure 5: Design of CSRR 4x4 Orientation, reduction of single cell (a) and $4 \times 4$ orientation (b).

\section{Results}

The simulation result of CSRR structure on microstrip patch array antenna as shown in Table 2 and Figure 6 . The additional CSRR effect is obtained by comparing the dimension and antenna performances parameter using CSRR structure and without CSRR structure.

TABLE 2: Performances and Dimension Comparison.

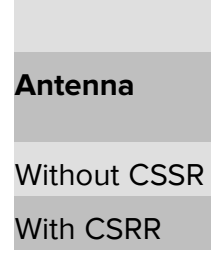

\begin{tabular}{|c|c|c|c|c|c|}
\hline \multicolumn{7}{|c|}{ Dimensions (mm) } \\
\hline Patch & $\begin{array}{c}\text { Substrate and } \\
\text { Ground }\end{array}$ & \multicolumn{2}{c|}{ Slot Inset } \\
\hline 37 & 29.7 & 112.66 & 68.95 & 0.6 & 13 \\
\hline 33.5 & 29.6 & 108.26 & 48.95 & 0.6 & 13 \\
\hline
\end{tabular}

Antenna Parameter

$(\mathrm{MHz}) \quad(\mathrm{dB}) \quad(\mathrm{dB})$

$\begin{array}{lll}50.8 & -22.89 & 6.4\end{array}$

$63.7-25.19 \quad 5.7$

To validate the simulation results, we measured the 2 element array antenna fabrication with the addition $4 \times 4$ CSRR structure as shown in Figure 7 . There were no 


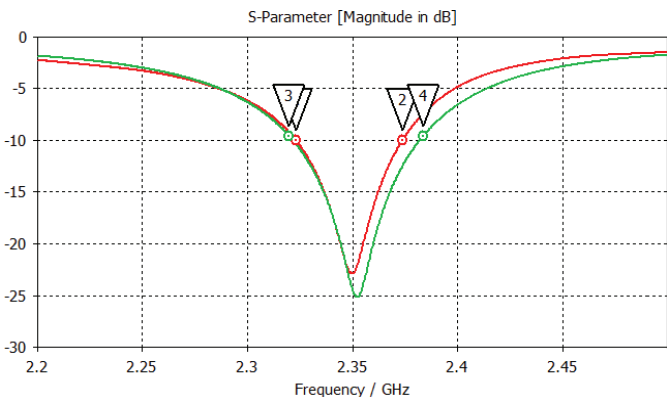

without CSSR

(a)

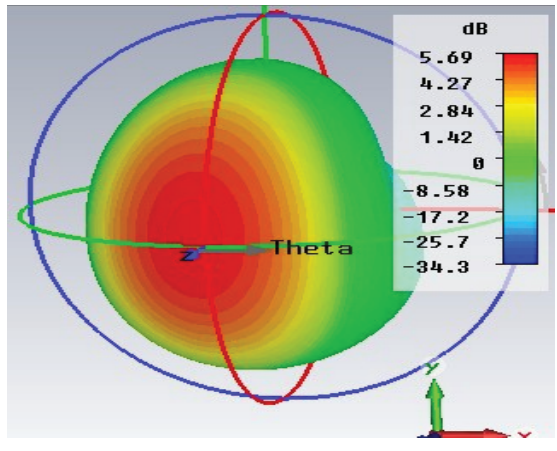

(b)

Figure 6: Simulation Result, parameter (a) and 3D radiation pattern (b).

significant differences between the simulation and measurement results as shown in Table 3.
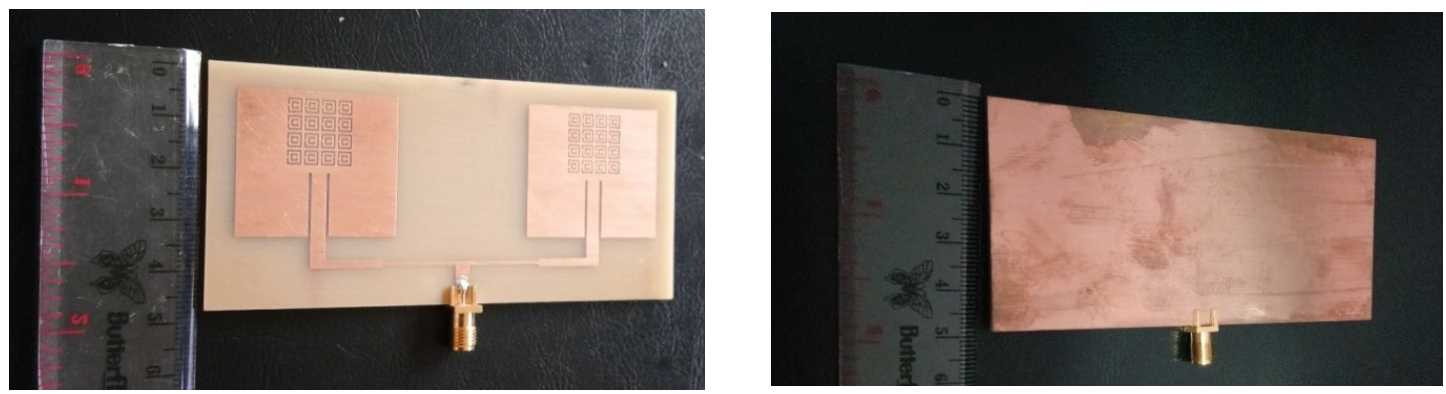

Figure 7: Fabrication of Array Antenna using CSRR, front view (a) and back view (b).

TABLE 3: Simulation and Measurement Comparison.

\begin{tabular}{|c|c|c|c|c|c|c|c|c|c|c|}
\hline \multirow{3}{*}{$\begin{array}{l}\text { Antenna } \\
\text { Without CSSR }\end{array}$} & \multicolumn{7}{|c|}{ Dimensions (mm) } & \multicolumn{3}{|c|}{ Antenna Parameter } \\
\hline & & \multicolumn{2}{|c|}{ Patch } & \multicolumn{2}{|c|}{$\begin{array}{l}\text { Substrate and } \\
\text { Ground }\end{array}$} & \multicolumn{2}{|c|}{ Slot Inset } & \multirow{2}{*}{$\begin{array}{c}\text { (MHz) } \\
50.8\end{array}$} & \multirow{2}{*}{$\begin{array}{c}(\mathrm{dB}) \\
-22.89\end{array}$} & \multirow[b]{2}{*}{1.154} \\
\hline & $\mathrm{S}$ & 37 & 29.7 & 112.66 & 68.95 & 0.6 & 13 & & & \\
\hline & M & 37 & 30.0 & 113.00 & 69.00 & 0.6 & 13 & 79.0 & -20.12 & 1.220 \\
\hline \multirow[t]{2}{*}{ With CSSR } & $\mathrm{S}$ & 33.5 & 29.6 & 108.26 & 48.95 & 0.6 & 13 & 63.7 & -25.19 & 1.116 \\
\hline & $M$ & 33.0 & 29.0 & 108.00 & 48.00 & 0.6 & 13 & 100.0 & -26.97 & 1.090 \\
\hline
\end{tabular}

\section{Discussion}

Simulation and measurements result of the array antenna with the addition of CSRR structures show that there is a significant reduction of antenna dimension compared to conventional array antenna (31.05\%). Antenna parameters also shows improved bandwidth and return loss, but there is a slightly decrease in gain. This is a consequence 
of the addition of CSRR structure, but compared to previous research this result shows an improvement of gain degradation. Future studies will be developed methods and techniques for adding CSRR structures to at least maintain gain performance.

\section{Conclusion}

A proposed design of metamaterial CSRR to reduce antenna dimension was described. The simulation and measurement result shown significant reduction of antenna dimension and improved bandwidth and return loss parameter with slightly decrease in gain. This proves that addition of CSRR structure is one of solution to miniaturization of microstrip antenna.

\section{Funding}

This work was supported by the FT Research Grant Universitas Negeri Jakarta, the Ministry of Research, Technology and Higher Education the Republic of Indonesia under Grant No. [461.a/SP/2018].

\section{Acknowledgement}

The authors would like to thank their colleagues for their contribution and support to the research. They are also thankful to all the reviewers who gave their valuable inputs to the manuscript and helped in completing the paper.

\section{Conflict of Interest}

The authors have no conflict of interest to declare.

\section{References}

[1] Amrutha. M., Anna. T., et al. (2015). Miniaturization of Microstrip Patch Antenna Using CSRR. IOSR Journal of Electrical and Electronics Engineering, vol. 10, pp. 16-20.

[2] Garg, R. (2000). Microstrip Antenna Design Handbook. Boston: Artech House.

[3] Limaye, A. (2006). Size Reduction of Microstrip Antennas Using Left-Handed Materials Realized by Complementary Split-Ring Resonators. Thesis, Rochester Institute of Technology. 
[4] Mustafa. K., Taher. A., William. G. W., et al. (2010). Compact Microstrip Band Stop Filter Using SRR and CSRR: Design, Simulation and Result, in Proceedings of the Fourth European Conference on Antennas and Propagation. IEEE Conference.

[5] Yuta. A., Toru. U., Takuji. A., et al. (2013). Frequency Band Widening of Negative Permeability Using Split-Ring Resonators, in Proceedings of 2013 International Symposium on Electromagnetic Theory.

[6] Muhammad, S. B., Omar, M. R., et al. (2012). Material Characterization Using Complementary Split-Ring Resonator. Journal IEEE Transactions on Instrumentation and Measurement, Vol. 61, pp. 3039-3046.

[7] Yadav, Mohanty. (2016). A Metamaterial Inspired UWB Antenna for WLAN Application. International Journal of Innovative Research in Science, Engineering and Technology, Vol. 5, pp. 10798-10805.

[8] Jianfeng. Z., Baotao. F., Shufang. L., et al (2015). Ultrawideband MIMO/Diversity Antenna Using CSRR Structure for Isolation Enhancement, in Proceedings of the 4th Asia-Pacific Conference on Antennas and Propagation (APCAP).

[9] Aidin. M., Tayeb. A., Abdel-Razik. S., et al. (2014). Multi-Band Miniaturized Antenna Loaded by ZOR and CSRR Metamaterial Structures with Monopolar Radiation Pattern. Journal IEEE Transactions on Antennas and Propagation, Vol. 62, pp. 555562. 